\title{
Perubahan Perilaku Open Defecation Free (ODF) melalui Program Sanitasi Total Berbasis Masyarakat (STBM) di Desa Babad Kecamatan Kedungadem Kabupaten Bojonegoro
}

\author{
Abdul Muhid ${ }^{1}$, Sumarkan ${ }^{2}$, Rakhmawati $^{3}$, Lukman Fahmi $^{4}$ \\ ${ }^{1}$ Fakultas Psikologi \& Kesehatan UIN Sunan Ampel Surabaya \\ abdulmuhid@uinsby.ac.id \\ ${ }^{2}$ Fakultas Syariah \& Hukum UIN Sunan Ampel Surabaya \\ ilhamullahsumarkan@yahoo.com \\ ${ }^{3}$ Fakultas Tarbiyah \& Kependidikan UIN Sunan Ampel Surabaya \\ thestarone_777@yahoo.com \\ ${ }^{4}$ Fakultas Dakwah \& Ilmu Komunikasi UIN Sunan Ampel Surabaya \\ lukmanfahmi21@gmail.com
}

\begin{abstract}
This research aimed to change the behavior of Open Defecation Free (ODF) through Total Sanitation Program of Community-Based. Through Community-Based Research (CBR) approach, it was possible that participatory researchers with communities and partners (stakeholders) preparing plans, conducting and evaluating research results. The results showed that the success of the program was determined by the level of Community participation in the planning, implementation, evaluation and until program sustainability. This was shown by the emergence of Community awareness to change the behavior of Open Defecation Free (ODF) and independently able to solve the problem of sanitation based community by building the decent toilet facilities in participatory. Changing in Open Defecation Free (ODF) behavior through Total Sanitation Program of Community-Based was strongly influenced by the availability of sanitation, the support of all parties, and the changing in the community's understanding of ODF. Total Sanitation Program of Community Based-participatory-based was very effective against the effort to change the behavior of defecation carelessly.
\end{abstract}

Keywords: Open Defecation Free (ODF), Total Sanitation Program of Community-Based, Community-Based Research (CBR)

\section{Pendahuluan}

Kabupaten Bojonegoro merupakan salah satu kabupaten di Provinsi Jawa Timur yang terletak pada koordinat $112^{\circ} 25-112^{\circ} 09$ bujur timur dan $6^{\circ} 59-7^{\circ} 37$ lintang selatan terdiri atas 27 kecamatan yang terbagi menjadi 430 desa. Luas wilayah seluruhnya adalah 2.384,02 km. Dengan keadaan topografi wilayah dataran rendah dan dataran tinggi yang dilalui aliran sungai Bengawan Solo, kabupaten Bojonegoro rentan akan perilaku buang air besar (BAB) di tempat terbuka atau yang disebut juga dengan istilah open defecation free (ODF). ${ }^{2}$

\footnotetext{
${ }^{1}$ Topografi Kabupaten Bojonegoro, dalam Buku Profil Bojonegoro dikutip dari www.kanalbojonegoro.com diunduh pada tanggal 21 Maret 2015.

2 Pengertian open defecation Free (ODF) adalah suatu tindakan membuang kotoran atau tinja di ladang, hutan, semak-semak, sungai, pantai atau area terbuka lainnya dan dibiarkan menyebar mengkontaminasi lingkungan, tanah, udara dan air. (dikutip dari WHO/UNICEF. Progress on Sanitation and Drinking-water: 2010 Update. Geneva: WHO
}

Volume 2, Number 1, Mei 2018|99

Perubahan Perilaku Open Defecation Free (ODF) Melalui Program Sanitasi Total Berbasis Masyarakat (STBM) di Desa Babad Kecamatan Kedungadem Kabupaten Bojonegoro

Abdul Muhid, Sumarkan, Rakhmawati, Lukman Fahmi 
Fenomena perilaku open defecation free (ODF) ini dapat dilihat sehari-hari pada masyarakat di desa-desa di kawasan bantaran sungai Bengawan Solo maupuan sungai-sungai lainnya yang memanjang dari kecamatan Margomulyo di ujung barat sampai kecamatan Baureno di ujung timur, masih banyak warga yang setiap pagi, siang dan sore menuju ke sungai, hanya untuk membuang hajat. Tidak hanya itu, Bengawan Solo dan sungai-sungai lainnya juga dipakai untuk kegiatan seharihari seperti mencuci, mandi, minum hewan dan lain sebagainya. ${ }^{3}$

Sebagian warga masyarakat di Kabupaten Bojonegoro selama ini masih buang air besar (BAB) di sungai Bengawan Solo maupun sungai-sungai lainnya yang jumlahnya ratusan di Bojonegoro, akan sangat berbahaya terhadap kesehatan. ${ }^{4}$ Sebab, sungai tersebut menjadi sumber konsumsi masyarakat, baik sebagai air minum, mencuci, mandi, dan keperluan domestik seharihari. Air yang tidak memenuhi persyaratan kesehatan tersebut rentan menjadi media penularan penyakit, karena air merupakan salah satu media kembang biak dari berbagai macam penularan penyakit, terutama penyakit perut. ${ }^{5}$

Pengelolaan sanitasi sangat berkait erat dengan kesehatan masyarakat. Karena tinja mempunyai dampak bagi kesehatan masyarakat. Beberapa penyakit yang dapat disebarkan oleh tinja manusia antara lain tipus, disentri, kolera, cacingan, pusing, penyakit kulit dan sebagainya. ${ }^{6}$ Beberapa penelitian menyebutkan tentang hubungan dan pengaruh antara sanitasi buruk oleh karakteristik dan perilaku kesehatan suatu masyarakat terhadap terjadinya penyakit infeksi. Diperkirakan 88\% (penelitian lain 90\%) kematian akibat diare di dunia disebabkan oleh kualitas air, sanitasi dan bigiene yang buruk. ${ }^{7}$ Sanitasi, personal bigiene dan lingkungan yang buruk berkaitan dengan penularan beberapa penyakit infeksi yaitu penyakit diare, kolera, typhoid fever dan paratyphoid fever, disentri, penyakit cacing tambang, ascariasis, hepatitis A dan E, penyakit kulit, trakhoma, schistosomiasis, cryptosporidiosis, malnutrisi dan beberapa penyakit yang berhubungan dengan malnutrisi. ${ }^{8}$

2010. p. 22-52); tentang penjelasan mengenai ODF dapat dirujuk dari beberapa literatur seperti: Mukherjee N. Factors Associated with Acbieving and Sustaining Open Defecation Free Communities: Learning from East Java. Water Sanitation Program (WSP): Research Breaf. September 2011. Hal. 1-8. Secara detail baca Nur Apriatman, Stop Buang Air Besar Sembarangan: Pembelajaran dari Pegiat Community Led-Total Sanitation (CLTS). Waspola Facility, Februari 2012.

${ }^{3}$ Tentang potret sungai Bengawan Solo lihat "Bojonegoro Tempo Doeloe" di Blok Bojonegoro: Tabloid Kritis Cerdas dan Terdepan, Edisi Oktober 2014.

${ }^{4}$ Harian Bhirawa Edisi 17 Pebruari 2015.

${ }^{5}$ Slamet. J. S. Kesehatan Lingkungan. (Yogyakarta: UGM Press, 2006). Hal. 3-4.

${ }^{6}$ Notoatmodjo, S. Pendidikan dan Perilaku Kesehatan. (Jakarta : Rineka Cipta, 2003). Hal. 15.

${ }^{7}$ Keusch GT, Fontaine, O, Bhargava, A. et.al. "Diarrheal Diseases". In: Jamison DT, editor. Disease Control Priorities in Developing Countries. 2nd edition. (Washington DC: World Bank 2006). Hal. 371 - 88.

${ }^{8}$ Tentang dampak sanitasi yang buruk terhadap sumber penyakit dapat ditemukan dalam beberapa penelitian

Volume 2, Number 1, Mei 2018| 100 Perubahan Perilaku Open Defecation Free (ODF) Melalui Program Sanitasi Total Berbasis Masyarakat (STBM) di Desa Babad Kecamatan Kedungadem Kabupaten Bojonegoro 
Akses masyarakat terhadap sarana sanitasi khususnya jamban atau water closet (WC), saat ini masih jauh dari harapan. Berbagai kampanye dan program telah banyak dilakukan, terakhir dengan pemberlakuan program Sanitasi Total Berbasis Masyarakat (STBM). ${ }^{9}$ Berbagai inovasi dan pengembangan sanitasi lingkungan telah dilakukan untuk mewujudkan masyarakat Bojonegoro bebas dari perilaku open defecation free (ODF), mulai dari pemicuan, monitoring dan evaluasi pemicuan juga dilakukan dengan memasang spanduk yang bersifat mengajak dan memicu kepada masyarakat untuk hidup bersih dan sehat yang ditempatkan di tempat-tempat yang strategi yang mudah dibaca oleh masyarakat.

Berdasarkan hasil penelitian sebelumnya menunjukkan bahwa hampir separuh masyarakat Indonesia masih berperilaku open defecation free (ODF). ${ }^{10}$ Berbagai upaya telah dilakukan oleh pemerintah untuk mengatasi persoalan tersebut, namun belum membuahkan hasil yang optimal, maka perlu terobosan lagi dalam mensukseskan program sanitasi tersebut. Adapun langkah yang dianggap tepat dalam mensukseskan program sanitasi ini diantaranya adalah Keputusan Menteri Kesehatan Nomor 852/MENKES/SK/IX2008 tentang program Sanitasi Total Berbasis Masyarakat. ${ }^{11}$ Program ini mengadopsi metode atau pendekatan Community Led-Total Sanitation (CLTS) sebagai metode yang digunakan dalam program-program peningkatan akses jamban bagi masyarakat.

Untuk dapat mendukung program Sanitasi Total Berbasis Masyarakat (STBM), perlu diidentifikasi tentang permasalahan sanitasi di wilayah Kabupaten Bojonegoro. Secara umum, kondisi wilayah Kabupaten Bojonegoro dilintasi aliran sungai Bengawan Solo dan ratusan sungai lainnya. Potensi air baku wilayah ini diperoleh dari air sungai-sungai tersebut, serta dari waduk dan mata air. Interaksi dan ketergantungan masyarakat warga Bojonegoro terhadap sungai telah berlangsung sejak lama, termasuk kebiasaan buang air besar di sungai. Di sisi lain, perilaku open

seperti Salma Galal et. all. "Infections in children under 5 years old and latrine cleanliness". International Journal of Environmental Health Research. 2001, (11):337-41. Carr R. "Excreta-related infections and the role of sanitation in the control of transmission". In: Bartram LFaJ, editor. Water Quality: Guidelines, Standards and Health. (London: IWA Publisihing 2001). p. 90 - 107. 5. Wagner EG, Lanoix,J.N. "Excreta Disposal for Rural Areas and Small Communities". WHO. 1958. Monograph Series. No.39:9 - 24. Cairncross S, Valdmanis, V. "Water Supply: Sanitation and Hygiene Promotion". In: Dean T Jamison ea, editor. Disease Control Priorities in Developing Countries. 2nd edition ed. (Washington DC: World Bank 2006. p. 771 - 92.

${ }_{9}^{9}$ Penjelasan mengenai program Sanitasi Total berbasis Masyarakat (STBM) bisa dibaca di situs-situs sebagai berikut: www.sanitasi.net; www.ampl.or.id ; dan www.stbm-indonesia.or.id

${ }^{10}$ Hasil studi Indonesian Sanitation Sector Development Program (ISSDP) tahun 2006, menunjukkan bahwa 47\% masyarakat Indonesia masih berperilaku buang air besar di sungai, sawah, kolam, kebun, dan tempat terbuka.

${ }^{11}$ Secara detail bisa dibaca salinan SK Menteri Kesehatan RI Nomor 852/MENKES/SK/IX2008 tentang program Sanitasi Total Berbasis Masyarakat.

Volume 2, Number 1, Mei 2018| 101 Perubahan Perilaku Open Defecation Free (ODF) Melalui Program Sanitasi Total Berbasis Masyarakat (STBM) di Desa Babad Kecamatan Kedungadem Kabupaten Bojonegoro 
defecation free (ODF) merupakan salah satu penyebab dari penyebaran kuman-kuman penyakit. ${ }^{12}$ Namun ada faktor sosial yang melanggengkan kebiasaan ini, yaitu di sepanjang tepian sungai menjadi tempat bertemu dan berinteraksi bagi anggota masyarakat sekitar. ${ }^{13}$ Upaya penyelesaian sanitasi ini layak dan perlu diperhatikan dengan mencermati aspek sosial dan budaya yang melatar belakangi perilaku open defecation free (ODF) masyarakat Bojonegoro.

Selama ini kesadaran masyarakat terhadap permasalahan sanitasi yaitu di mana kondisi lingkungan yang kurang sehat, perilaku masyarakat yang masih sering buang air besar (BAB) di sungai, di lahan kosong, dan di tempat-tempat terbuka lainnya. Di sini faktor alam yang kuat mempengaruhi perilaku open defecation free (ODF). Permasalahan lain yang muncul adalah pelayanan kesehatan yang belum merata, akses kesehatan masyarakat yang terbatas dan kurangnya tenaga kesehatan. Kondisi ekonomi masyarakat yang masih lemah dan tingkat pendapatan yang masih rendah, mengakibatkan pola kehidupan masyarakat yang kurang peduli akan kesehatan sanitasi mereka, khususnya kondisi jamban dan air bersih serta persoalan kualitas kesehatan lainnya. ${ }^{14}$

Salah satu desa di kabupaten Bojonegoro yang perlu perhatian terkait masalah perilaku open defecation free (ODF) adalah Desa Babad Kecamatan Kedungadem. Gambaran perilaku hidup sehat pada masyarakat Desa Babad tercermin seperti masalah minimnya kesadaran masyarakat terhadap kesehatan lingkungan ini juga dapat dilihat dari banyaknya rumah masyarakat yang dijadikan sebagai kandang bagi hewan peliharaannya. Padahal kondisi yang seperti ini tidak baik bagi kelangsungan kehidupan manusia. Kondisi rumah akan mudah terpengaruh oleh bakteri, kuman atau bahkan virus yang dibawa oleh hewan ternak sehingga menyebabkan rentannya terserang penyakit bagi penghuni rumah.

Selain itu, minimnya perhatian masyarakat terhadap pengadaan sarana Mandi Cuci Kakus (MCK) juga menjadi problem utama di desa tersebut. Tidak seperti masyarakat pada umumnya yang memiliki kesadaran terhadap pentingnya sarana MCK sehingga sebagian besar masyarakat desa memiliki sarana MCK, justru hanya sebagian kecil masyarakat Desa Babad yang memiliki sarana MCK. Masyarakat Desa Babad yang tidak memiliki sarana MCK cenderung memanfaatkan

12 Umar Zein, Khalid Huda Sagala, Josia Ginting. "Diare Akut Disebabkan Bakteri”. Fakultas Kedokteran Divisi Penyakit Tropik dan Infeksi Bagian Ilmu Penyakit Dalam Universitas Sumatera Utara. Laporan Penelitian diunduh dari e-USU Repository (C2004 Universitas Sumatera Utara.

${ }^{13}$ Baca Rochgianti, "Fungsi Sungai bagi Masyarakat di Tepian Sungai Kuin Kota Banjarmasin”, Jurnal Komunitas 3 (1) (2011) : 51-59. Potret masyarakat tepi sungai dan perilaku BAB dapat dibaca pada laporan hasil penelitian Farah Nur Amalina Nurjanah Massudi Suwand, Perilaku Bab Di Sungai Pada Warga Di Kelurahan Sekayu Semarang Tabun 2014. Fakultas Kesehatan Universitas Dian Nuswantoro Semarang.

${ }_{14}$ Ambar Winarti, Suci Nurmalasari, "Hubungan Perilaku Buang Air Besar (BAB) dengan Kejadian Diare di Desa Krajan Kecamatan Jatinom Kabupaten Klaten, Jurnal Involusi Kebidanan, Vol. 7, No. 12, Juni 2016. 13-25. 
sungai sebagai tempat untuk pembuangan tinja secara masal. Terkadang masyarakat juga membuang tinja di bawah pohon di samping rumah atau lahan kosong lainnya. ${ }^{15}$

Berdasarkan sensus penduduk terhadap masyarakat Desa Babad, hanya terdapat sedikit masyarakat yang memiliki kesadaran akan pentingnya sarana MCK. Seperti tergambar pada fakta di Dusun Kalitengah, hanya terdapat 13 rumah yang memiliki water closet (WC) dan 152 rumah yang tidak memiliki water closet (WC). Kurangnya kesadaran masyarakat terhadap pentingnya sarana MCK ini disebabkan karena anggapan masyarakat yang cenderung mengeluarkan banyak biaya untuk pengadaan sarana MCK. Sebagai akibat dari kurangnya kesadaran masyarakat ini menyebabkan tercemarnya sungai dan lingkungan sekitar. Apalagi ketika musim hujan tiba yang menyebabkan aliran sungai meluap, sehingga tidak heran jika banyak masyarakat yang terserang berbagai penyakit seperti diare, gatal-gatal dan penyakit kulit lainnya. ${ }^{16}$

Fakta di masyarakat dapat ditemu-kenali bahwa mereka cenderung enggan untuk membuat sarana MCK yang memadai meskipun pihak pemerintah desa pernah memberikan sumbangan/pengadaan closet. Keengganan masyarakat tersebut bermula dari kurang lancarnya sarana air bersih di setiap rumah, meskipun Desa Babad ini memiliki potensi sumber air yang besar yang terletak di Dusun Boro. Selain itu sedikitnya masyarakat yang memiliki sumur menjadi salah satu faktor penyebab keengganan masyarakat membuat sarana tempat MCK yang memadai. Salah satu dusun di desa Babad misalnya Dusun Banaran hanya 50 rumah yang memiliki sumur dan 242 rumah lainnya tidak memiliki sumur. Oleh karena itu masyarakat cenderung memilih untuk buang air besar di sungai karena lebih hemat dan efisien, tanpa mengeluarkan biaya sepeser pun. ${ }^{17}$

Berdasarkan deskripsi kondisi obyektif komunitas dampingan tersebut di atas, perlu penelitian lebih lanjut tentang bagaimana perubahan perilaku open defecation free (ODF) melalui program Sanitasi Total Berbasis Masyarakat (STBM) yang selama ini dilaksanakan oleh komunitas. Melalui pendekatan community-based research (CBR) dimungkinkan secara partisipatif peneliti bersama komunitas dan mitra (stakeholders) menyusun rencana, melakukan dan mengevaluasi hasil penelitian sebagai upaya perubahan perilaku open defecation free (ODF) melalui program Sanitasi Total Berbasis Masyarakat (STBM) di Desa Babad Kec. Kedungadem Kabupaten Bojonegoro.

${ }^{15}$ Miftakhul Rizeki Hardiyansah dkk. "Membebaskan Masyarakat Dari Perilaku ODF Menuju Desa Sehat: Pendampingan Warga dalam Mengubah Kebiasaan Buang Air Besar Sembarangan di Sungai Menjadi Buang Air Besar di WC di Dusun Banaran Desa Babad Kecamatan Kedungadem Kabupaten Bojonegoro". LP2M UINSA: Laporan KKN Transformatif Tahun 2015. Tidak Diterbitkan.

16. Miftakhul Rizeki Hardiyansah dkk. "Membebaskan... Hal 25.

${ }^{17}$ Hasil wawancara dengan bapak kepala dusun sugianto. Senin, 26 januari 2015. 10.00 WIB

Volume 2, Number 1, Mei 2018| 103 Perubahan Perilaku Open Defecation Free (ODF) Melalui Program Sanitasi Total Berbasis Masyarakat (STBM) di Desa Babad Kecamatan Kedungadem Kabupaten Bojonegoro 


\section{Metode}

Penelitian ini menggunakan metode Community-Based Research (CBR) yaitu penelitian bersama masyarakat untuk mengatasi permasalahan yang dialami masyarakat. Pendekatan CBR ini sangat sesuai dengan tujuan pendampingan komunitas yang dilakukan yaitu bagaimana mengubah perilaku perilaku open defecation free (ODF) melalui program Sanitasi Total Berbasis Masyarakat (STBM) yang selama ini dilaksanakan oleh komunitas. Dengan menggunakan metode CBR dimungkinkan adanya kerja sama antara peneliti dengan komunitas dampingan dalam melakukan setiap tahapan penelitian mulai dari rancangan penelitian sampai diseminasi hasil penelitian. ${ }^{18}$ Desain kegiatan penelitian partisipatif ini berpijak pada peran dari berbagai pihak baik dari kalangan akademik atau anggota masyarakat bersifat resiprokal, timbal-balik yang saling mengutungkan, partisipatoris, dan kolaboratif.

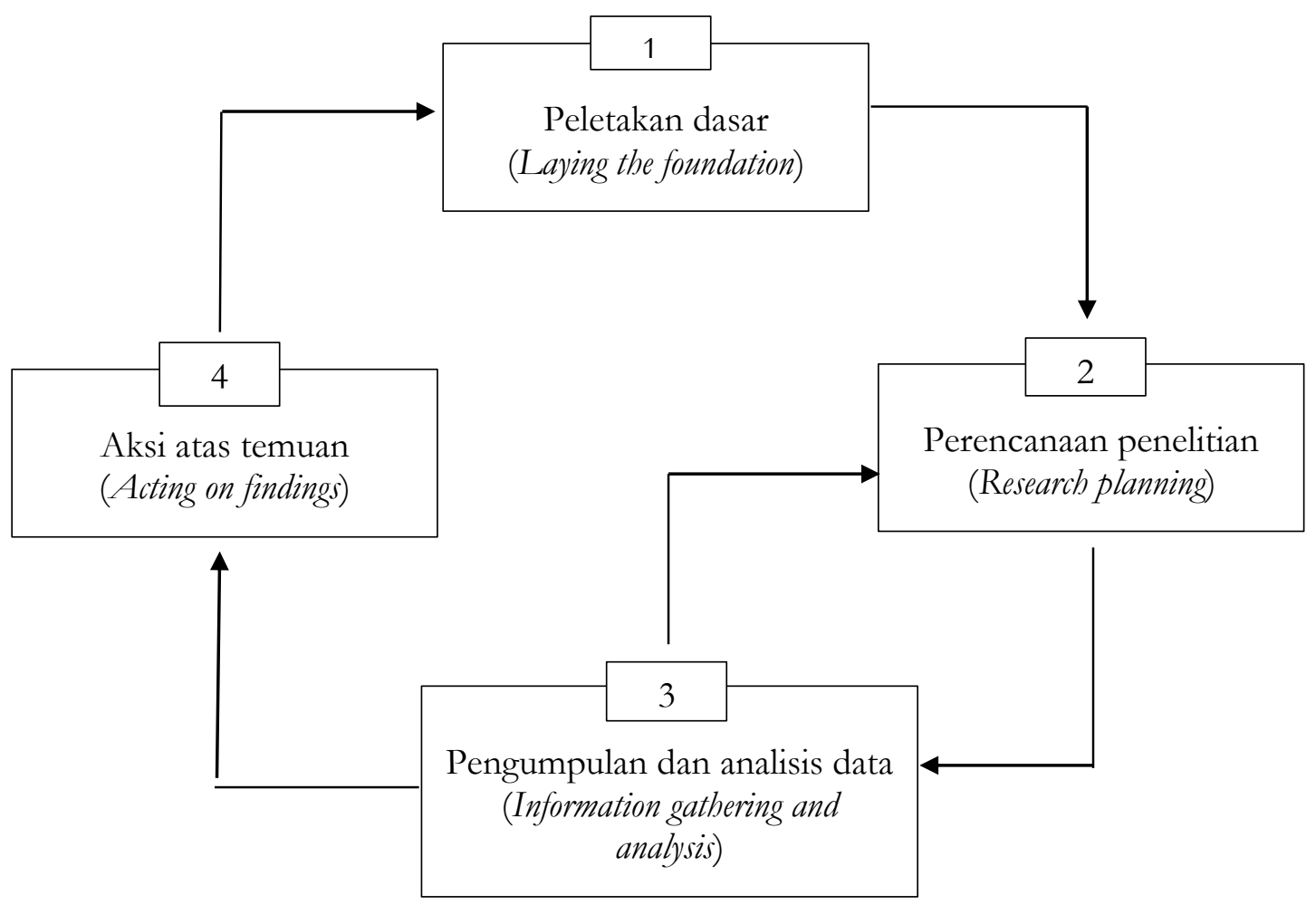

Gambar 1: Empat Tahap dalam $\mathrm{CBR}^{19}$

${ }^{18}$ Hanafi, dkk., Community-Based Research: Panduan Merancang dan Melaksanakan Penelitian Bersama Komunitas, (Surabaya: LP2M UIN Sunan Ampel Surabaya bekerjasama dengan Dwiputra Pustaka Jaya, 2015), hal. 33.

${ }^{19}$ Hanafi, dkk., Community-Based ...Hal. 55.

Volume 2, Number 1, Mei 2018| 104 Perubahan Perilaku Open Defecation Free (ODF) Melalui Program Sanitasi Total Berbasis Masyarakat (STBM) di Desa Babad Kecamatan Kedungadem Kabupaten Bojonegoro 
Community-Based Research (CBR) sebagai metode riset dalam praktiknya bahwa dalam proses pelaksanaan penelitian dilakukan bersama komunitas dengan para akademisi dari universitas untuk mengeksplorasi dan menciptakan peluang-peluang bagi terjadinya aksi sosial dan perubahan sosial (social transformation). ${ }^{20}$ Community-Based Research (CBR) sebagai penelitian yang belakangan memayungi dua tradisi besar pendekatan penelitian yaitu action research dan participatory research, maka tahapan penelitian dalam CBR ini secara garis besar mengandung prinsip yang berakar pada pendapat Kurt Lewin, yaitu sebagai prinsip siklikal spiral yang meliputi perencanaan, pelaksanaan dan pengamatan. ${ }^{21}$

Menurut Joanna Ochocka dari Center for Community-Based Research Kanada, bahwa ada 4 (empat) tahapan dalam proses penelitian dengan metode CBR, yaitu: peletakan dasar (laying foundation), Perencanaan (planning), pengumpulan dan analisis data (information gathering and analysis) dan aksi atas temuan (acting on finding). ${ }^{22}$ Selanjutnya tahapan pelaksanaan penelitian sesuai dengan tahapan dalam metode CBR, yaitu dapat dilihat pada Gambar 1.

Berdasarkan empat tahapan pada Gambar 1. tersebut, maka kegiatan penelitian ini didesain sebagai berikut:

1. Tahap Laying the Foundation: melibatkan komunitas yang ada di Desa Babad (pamong desa, tokoh masyarakat, tokoh agama, kelompok remaja, kelompok ibu-ibu PKK, dan kelompok pengajian) dalam keseluruhan proses penelitian. Pada tahapan awal ini ditetapkan kesepakatan tentang bagaimana cara mengubah perilaku open defecation free (ODF), melalui seringkaian kegiatan focus group discussion (FGD) secara berkelanjutan mendiskusikan tujuan penelitian dan melakukan pembagian peran masing-masing, baik dari unsur peneliti maupun komunitas. Pada tahap ini juga dilakukan pengenalan terhadap gambaran umum kehidupan dan kondisi komunitas mitra penelitian melalui proses inkulturasi sebagai upaya trust building masing-masing pihak yang terlibat. Selain itu, kegiatan negotiating goals and roles ini dilakukan melalui teknik mengorganisir stakeholders (para pemangku kepentingan) serta memperjelas perannya masingmasing, mengorganisir dan mengidentifikasi asumsi yang berkembang dalam komunitas untuk diteliti, memperjelas konteks penelitian, serta menentukan tujuan akhir dari penelitian.

\footnotetext{
${ }^{20}$ Brenda Roche, New Directions in Community-Based Research, Wellesley Institute, 2008, dikutip dari http://www.wellesleyinstitute.com/wp-content/uploads/2011/11/newdirectionsincbr.pdf.

${ }^{21}$ Stephen Kemmis and Robin Mc. Taggart, Participatory Action Research dalam Norman K. Denzin \& Yvonna S. Lincoln, Handbook of Qualitative Research (California: Sage Publication, 2000).

22 Joanna Ochocka, Materi Training CBR in CCBR-Kitchener Canada, Oktober, 2014
}

Volume 2, Number 1, Mei 2018| 105 Perubahan Perilaku Open Defecation Free (ODF) Melalui Program Sanitasi Total Berbasis Masyarakat (STBM) di Desa Babad Kecamatan Kedungadem Kabupaten Bojonegoro 
2. Tahap Research Planning: merupakan tahap negotiating perspectives to illuminate yaitu sudah disepakati dan muncul kesepahaman antara peneliti dengan komunitas terkait dengan bagaimana mendesain kegiatan penelitian dalam upaya perubahan perilaku open defecation free (ODF). Pada tahap ini telah disepakati proses kegiatan dan prioritas utama dalam rangka upaya pengubahan perilaku open defecation free (ODF). Berdasarkan analisis potensi komunitas, individual skill, social capital, aset budaya, dan sumber daya lainnya yang dimiliki komunitas dengan mempertimbangkan kendala waktu dan biaya telah disepakati kegiatan akasi partisipatori untuk mencapai perubahan sosial (social transformation). Pelibatan semua unsur warga masyarakat yang ada di Desa Babad menjadi acuan dalam tahap proses perencanaan kegiatan ini.

3. Tahap Information Gathering and Analysis: merupakan tahap negotiating meaning and learning, yaitu proses pemaknaan dan pembelajaran melalui mengumpulkan, menganalisis dan mengintrepretasi data bersama komunitas. Pengumpulan data dalam penelitian ini menggunakan metode yang biasa dilakukan dalam penelitian partisipatori. Beberapa metode dan teknik yang dilakukan adalah depth interview, observasi, dokumentasi, FGD, story telling, mapping komunitas, transect, kalender musim, trend change, matriks ranking, dan lain-lain.

4. Tahap Acting on Findings: merupakan tahap memobilisasi pengetahuan (knowledge mobilitation) masyarakat tentang temuan-temuan hasil riset. Pada tahap ini peneliti bersama komunitas menetapkan sarana/media informasi yang tepat dalam mengkapanyekan program bebas dari perilaku open defecation free (ODF). Beberapa strategi yang dilakukan dalam rangka menyebarkan informasi dan model aksi atas hasil riset bersama ini yang disepakati antara lain adalah melalui media kesenian rakyat, teater, drama, pembuatan film "Iklan Layanan Masyarakat Bebas ODF", dan lain sebagainya. Tindak lanjut penelitian ini juga disepakati beberapa kegiatan lanjutan yang bertujuan untuk mengaplikasikan hasil penelitian agar terjadi perubahan dalam masyarakat sesuai dengan harapan yang sudah dilakukan dalam research planning. Salah satunya adalah mendiseminasikan hasil temuan penelitian ini dengan para stakeholders seperti pihak PUSKESMAS, Pemerintah Kecamatan Kedungadem, dan Pemerintah Kabupaten Bojonegoro melalui Dinas Kominfo.

\section{Hasil dan Pembahasan}

Pemerintah Desa Babad Kecamatan Kedungadem Kabupaten Bojonegoro sejatinya telah memiliki program kerja yang tersusun dalam dua puluh (20) indikator, terbagi dalam dua indikator besar yaitu indikator cerdas dan indikator sehat. Setelah dilakukan survei partisipatif ke seluruh

Volume 2, Number 1, Mei 2018| 106 Perubahan Perilaku Open Defecation Free (ODF) Melalui Program Sanitasi Total Berbasis Masyarakat (STBM) di Desa Babad Kecamatan Kedungadem Kabupaten Bojonegoro 
dusun yang ada di Desa Babad akhirnya ditemukan bahwa masalah kesehatan masyarakat merupakan salah satu masalah yang paling penting diantara sekian masalah yang menjadi perhatian utama masyarakat setempat. Di lihat dari keseluruhan dusun yang terdapat di Desa Babad, sarana MCK (Mandi, Cuci, Kakus) menjadi masalah umum bagi masyarakat. Kesadaran akan pentingnya sarana MCK yang layak masih menjadi persoalan di tengah-tengah bersoalan kehidupan di masyarakat. Selama ini belum ada upaya secara signifikan untuk menyelesaikan masalah ini, pada hal sarana MCK yang layak merupakan kebutuhan vital dalam keseharian waga masyarakat.

Hasil survei menunjukkan bahwa di Dusun Banaran yang terdapat 242 rumah (KK), yang memiliki water closet (WC) hanya 93 rumah (KK) atau hanya 38\% saja yang memiliki water closet (WC). Hal ini sungguh ironis mengingat bahwa sekitar 62\% masyarakat lainnya memanfaatkan sungai yang mengalir di desa ini sebagai sarana buang hajat. Hasil wawancara dan observasi partisipatif menemukan fakta bahwa praktik buang air besar (BAB) masyarakat juga dilakukan di pekarangan atau lahan kosong dengan cara menggali tanah di bawah pepohonan dan di tengah rimbunnya pohon bambu untuk melakukan buang hajat. Padahal selama ini sejatinya warga masyarakat sadar bahwa perilaku BAB sembarangan tersebut sangat berbahaya dan tidak memenuhi kepantasan secara sosial. Dari hasil wawancara dan cerita dari warga masyarakat ditemukan fakta tentang beberapa peristiwa yang dapat menjadi pertimbangan akan pentingnya buang air besar di tempat semestinya seperti di sarana MCK yang memadai. Pertimbangan kepantasan secara sosial yang menggangu dan menjadi masalah sosial diantaranya adalah terjadi peristiwa perselingkuhan yang disebabkan oleh terlihatnya anggota tubuh (aurat) saat buang air besar di sungai atau di tempat terbuka lainnya. Kejadian yang membahayakan nyawa saat BAB di tempat terbuka yaitu peristiwa yang mengenaskan seorang bapak yang sedang buang air besar di bawah pohon bambu kemudian bapak tersebut digigit ular hingga akhirnya meninggal dunia. Berdasarkan beberapa kejadian yang ada di masyarakat tersebut, dapat diapahami bahwa buang air besar di sembarang tempat (open defecation free) sangatlah berbahaya bagi kesehatan masyarakat, pencemaran lingkungan, etika dan hubungan sosial warga masyarakat, dan keamanan terhadap nyawa pun terancam.

Selain itu, permasalahan sarana penyediaan air bersih dan biaya pengadaan sarana MCK yang layak menjadi masalah yang tidak kalah penting. Masyarakat selama ini merasa tidak memiliki biaya untuk menyediakan sarana MCK, hal itu dipengaruhi oleh persepsi warga masyarakat tentang besaran biaya yang cukup besar untuk pengadaan atau pembuatan MCK ini, sehingga masyarakat lebih memilih buang air besar ke sungai yang ada aliran air tanpa harus menimba dan mengangkut

Volume 2, Number 1, Mei 2018| 107 Perubahan Perilaku Open Defecation Free (ODF) Melalui Program Sanitasi Total Berbasis Masyarakat (STBM) di Desa Babad Kecamatan Kedungadem Kabupaten Bojonegoro 
air dari sumur. Sejatinya Pemerintah Kaupaten Bojonegoro selama ini sudah menaruh perhatian terhadap permasalahan ini. Pemerintah bekerja sama dengan aparat setempat menyelenggarakan kegiatan penyuluhan tentang bahaya buang air besar di sungai. Namun kegiatan ini tidak berpengaruh secara signifikan terhadap kebiasaan masyarakat buang air besar (BAB) di sungai.

Di samping kegiatan pemberian penyuluhan oleh Dinas terkait, Pemerintah selama ini juga memberikan bantuan penyediaan fasilitas MCK umum untuk warga Dusun Banaran Desa babad. Penyediaan sarana MCK umum ini diletakkan di tempat strategis yaitu di dekat Balai Desa setempat. Dampaknya, selama ini masyarakat yang memanfaatkan sarana MCK umum tersebut mulai sedikit demi sedikit sadar dan mengubah perilaku dari buang air besar (BAB) di sungai pindah ke MCK umum tersebut. Namun, karena dalam perawatannya kurang diperhatikan oleh masyarakat, menyebabkan MCK umum tersebut tidak terawat, sehingga perilaku masyarakat kembali lagi seperti semula yaitu buang air besar ke sungai, dan dibiarkan saja MCK umum tersebut sampai mengalami kerusakan dan sangat kotor. MCK umum tersebut lama kelamaan akhirnya rusak sehingga tidak dapat digunakan lagi oleh warga, dan masyarakat pun kembali membuang air besar di sungai atau di tempat terbuka lainnya.

Mengetahui hal tersebut, Pemerintah Desa mencoba mengeluarkan kebijakan dengan memberikan bantuan lima puluh (50) unit closet gratis kepada warga masyarakat terpilih dengan tujuan untuk memberikan contoh bagi warga masyarakat supaya buang besar di tempat semestinya misalnya di water closet (WC). Selain itu, juga dengan pemberian bantuan closet gratis supaya menumbuhkan kesadaran bagi warga masyarakat tidak buang air besar sembarangan lagi. Namun, pada kenyataanya ternyata warga masyarakat yang mendapat bantuan closet tersebut tidak otomatis langsung menggunakannya untuk penyediaan sarana MCK. Karena rendahnya kesadaran dan kurangnya partisipatif dalam kebijakan ini, warga masyarakat masih mengharap bantuan biaya pembuatan/pembangunan sarana MCK dari pihak pemerintah desa. Mereka beralasan karena tidak mimiliki biaya yang cukup untuk membangun MCK yang layak.

Pihak aparat Pemerintah Desa selama ini juga telah memberlakukan beberapa peraturan guna mengatasi persoalan open defecation free (ODF) ini. Melalui "rembug" desa disepakati peraturan desa yang dinamakan "angger-angger" yaitu peraturan yang menyatakan bahwa barangsiapa yang membuang air besar di sungai akan didenda sebesar Rp. 10.000,00-. Namun, hal ini tidak membawa dampak yang signifikan dalam mengatasi permasalahan buang air besar (BAB) di sungai. Aksi lain yang dilakukan oleh pemerintah Desa guna mengurangi praktik perilaku open defecation free (ODF) ini yaitu dengan menambahkan lampu jalan di sepanjang tepi sungai guna meningkatkan rasa malu

Volume 2, Number 1, Mei 2018| 108 Perubahan Perilaku Open Defecation Free (ODF) Melalui Program Sanitasi Total Berbasis Masyarakat (STBM) di Desa Babad Kecamatan Kedungadem Kabupaten Bojonegoro 
warga masyarakat agar tidak lagi membuang air besar di sungai. Namun, hal ini juga tidak membuat masyarakat "jera" untuk membuang air besar di sungai. Tidak berhenti sampai di sini upaya pemerintah desa dalam upaya mengurangi perilaku open defecation free (ODF). Bersama tokoh agama dan tokoh masyarakat seperti Modin Desa, dan petugas pencatat nikah (PPN), pemerintah membuat Peraturan Desa yaitu mewajibkan warga masyarakat membangun sarana MCK di rumah sebelum melaksanakan acara perhelatan pernikahan. Apabila tidak dipenuhi ketentuan tersebut, pihak aparat desa dan PPN tidak akan memberikan pelayanan administrasi pengurusan surat nikah.

Berdasarkan kondisi obyektif komunitas dampingan tersebut, bersama core group yaitu Kepala Desa Babad, Kepala Dusun (Pakwo) Banaran, beberapa perwakilan RT dan tokoh masayarakat dan warga Dusun Banaran melakukan Focus Group Discussion (FGD) untuk mendesain aksi sebagai upaya dapat menyelesaikan permasalahan tersebut. Dalam kegiatan/aksi pendampingan tersebut tim pendamping berperan sebagai fasilitator guna menfasilitasi komunitas untuk bersama-sama melakukan aksi pemecah masalah terkait dengan perilaku buang air besar sembarangan atau open defecation free (ODF). Harapannya supaya dapat mengarahkan masyarakat untuk tidak lagi membuang air besar di sungai melainkan membuang air besar di water closet (WC). Focus Group Discussion (FGD) dilakukan bersama aparat Desa Babad seperti kepala Desa beserta jajarannya. Dalam FGD ini tim fasilitator dan aparat Desa Babad memperkenalkan program yaitu stop buang air besar sembarangan (ODF). Program ini bertujuan untuk mengajak dan menjalin kerjasama antara tim fasilitator, aparat desa dan warga masyarakat guna mencari solusi secara bersama-sama terkait buang air besar (BAB) sembarangan.

Tim fasilitator berupaya menjalin hubungan kerjasama yang baik dengan aparat Desa Babad. Agar nantinya dalam menjalankan program dapat sepenuhnya mendapat dukungan dan kerjasama dengan perangkat desa setempat. Kepala Dusun Banaran Desa Babad menuturkan bahwa penyebab masyarakat enggan membuang air besar di water closet (WC) adalah dikarenakan masyarakat tidak memiliki biaya untuk membuat water closet(WC). Hal ini karena masyarakat sebagai petani saat-saat memiliki biaya untuk membuat water closet (WC) hanya pada saat tiba masa panen. Masa panen petani setelah menanam bibit adalah tiga bulan. Sehingga petani tidak memiliki simpanan uang yang cukup untuk membuat water closet (WC). Sekalipun mereka telah panen, mereka tidak memiliki uang simpanan karena uang tersebut telah mereka gunakan untuk memenuhi kebutuhan hidup sehari-hari.

Selain penjelasan Kepala Dusun tersebut, Kepala Desa Babad juga menuturkan bahwa pemerintah Desa telah bekerja sama dengan masyarakat setempat untuk mengatasi pemasalahan

Volume 2, Number 1, Mei 2018| 109 Perubahan Perilaku Open Defecation Free (ODF) Melalui Program Sanitasi Total Berbasis Masyarakat (STBM) di Desa Babad Kecamatan Kedungadem Kabupaten Bojonegoro 
buang air sembarangan (ODF) ini. Selama ini pemerintah Kabupaten Bojonegoro telah memiliki program yang dinamakan GDSC atau singkatan dari “Gerakan Desa Sehat dan Cerdas". Untuk merealisasikan program pemerentah Kabupaten ini, aparat Desa bekerja sama dengan pemerintah Kabupaten melakukan penyuluhan dan pembinaan terhadap masyarakat agar mengubah kebiasaan buang air besar di sembarang tempat atau di sungai beralih buang air besar di water closet (WC). Namun, dalam pelaksanaannya kebijakan pemerintah Desa ini kurang mendapat sambutan positif dari masyarakat. Hal ini disebabkan masyarakat mengharap bantuan lebih dalam wujud material dan WC yang dibangun bukanlah seperti "jumbleng" (kakus) tetapi mereka menginginkan water closet (WC) yang dengan dinding keramik. Hal ini tentu saja membuat aparat Desa merasa keberatan, namun bagaimanapun program "Gerakan Desa Sehat dan Cerdas" (GDSC) harus diwujudkan.

Berdarasarkan temuan di lapangan terutama pada sesi-sesi kegiatan focus group discussion (FGD), menunjukkan bahwa masyarakat enggan membangun sarana MCK dan water closet (WC) yang layak disebabkan karena beberapa macam faktor. Faktor tersebut antara lain rendahnya pengetahuan masyarakat tentang bahaya perilaku open defecation free (ODF), rendahnya tingkat kesadaran masyarakat untuk tidak ODF, rendahnya tingkat kesadaran masyarakat akan akibat negatif dari ODF, dan pembiaran masyarakat berperilaku ODF oleh warga masyarakat. Berdasarkan faktor-faktor tersebut selanjutnya bersama komunitas melalui sesi kegiatan focus group discussion (FGD) mencari solusi dari masalah mengubah perilaku open defecation free (ODF) tersebut. Salah satu kesepatakan dengan komunitas adalah membuat "arisan WC" untuk menyelesaikan permasalahan mengubah perilaku open defecation free (ODF). Sayangnya kesepakatan bersama komunitas tersebut ditanggapi oleh masyarakat secara tidak responsif, dan bahkan ada sebagian masyarakat yang menolak usulan tersebut, meskipun sebagian masyarakat yang lain mendukung adanya "arisan WC". Alasan beberapa warga masyarakat yang menolak adalah karena mereka merasa masih banyak tanggungan yang harus dibayar oleh masyarakat sehingga tidak dapat membangun sarana MCK yang memadai. Menurut mereka, membangun sarana MCK yang layak itu membutukan biaya yang cukup besar.

Selanjutnya, dalam kegiatan focus group discussion (FGD) yang melibatkan komunitas perempuan (ibu-ibu) yang tergabung dalam jamaah (kumpulan) tablilan-yasinan Dusun Banaran Desa Babad dengan agenda menindak lanjuti solusi untuk mengatasi perilaku open defecation free (ODF). Pada pertemuan focus group discussion (FGD) ini, dilakukan diskusi untuk mencari solusi penyelesaian masalah perilaku open defecation free (ODF), yaitu diusulkan "arisan WC". Pada saat "rembug" untuk menyelesaikan masalah kesehatan lingkungan ini, sebagian perempuan mengajukan usulan untuk

Volume 2, Number 1, Mei 2018| 110 Perubahan Perilaku Open Defecation Free (ODF) Melalui Program Sanitasi Total Berbasis Masyarakat (STBM) di Desa Babad Kecamatan Kedungadem Kabupaten Bojonegoro 
mengungkapkan solusi-solusi yang lain yang dapat dijadikan bahan pertimbangan untuk memecahkan masalah perilaku open defecation free (ODF). Usulan yang terungkap dalam FGD tersebut antara lain seperti iuran masyarakat untuk membeli material berupa dekker yang dapat digunakan untuk membuat WC, masing-masing keluarga membangun WC di rumah masingmasing dengan proses pembuatannya dibantu oleh tim fasilitator.

Kegiatan fasilitasi komunitas selanjutnya yaitu melakukan kegiatan focus group discussion (FGD) lanjutan yang dilakukan dengan melibatkan unsur dalam masyarakat yaitu perwakilan perempuan (ibu-ibu) dari masyarakat Dusun Banaran Desa Babad, Kepala Dusun, para ketua RW dan RT, dan tokoh masyarakat setempat. Dalam FGD kali ini, masyarakat sepakat bahwa akan mengadakan "iuran” untuk membuat sarana MCK. Selain itu juga diusulkan untuk menjalin kerjasama dengan berbagai pihak seperti lembaga pemerintah maupun swasta untuk membantu menyelesaikan problem ODF di Dusun Banaran Desa Babad ini. Berdasarkan hasil FGD bersama warga masyarakat telah disepakati bahwa untuk mengatasi masalah perilaku open defecation free (ODF), komunintas secara gotong royong membuat sarana MCK dengan biaya bersumber dari "iuran masyarakat" dan juga hasil partisipasi dari sebagian masyarakat secara suka rela. Berdasarkan hasil iuran terkumpul sebesar Rp. 1.200.000.00,- sedangkan dari hasil partispasi komunitas tekumpul dana sebesar Rp. 2.200.000.00,- sehingga sejumlah total adalah Rp. 3.400.000.00,- Dari uang tersebut kemudian dapat dibuat sebanyak 6 unit water closet (WC) untuk 6 rumah warga yang paling miskin secara berbeda.

Selanjutnya, bersama komunitas dan didukung oleh tukang batu setempat (ahli bangunan) disusunlah anggaran belanja untuk pembuatan water closet (WC) masing-masing tiap unit. Selanjutnya dibelikan (pengadaan) barang atau material bahan baku pembuatan water closet (WC) dan langsung mendistribusikan bahan material tersebut beserta peralatan tersebut didistribusikan menuju rumah-rumah yang akan dibantu pembuatan MCK dengan water closet (WC) "urunan" tersebut. Bahan baku tersebut antara lain: PVC winlon 1,5’ D, bis atau dekker dengan tutup berdiameter 60, T 1,5, keni 1, 5, semen gresik, PVC winlon 3' D, keni 3, pasir, bata. Hasil focus group discussion (FGD) bersama komunitas dan difasilitasi oleh Kepala Dusun Banaran dan ketua RT, maka disepakati model atau prototype water closet (WC) yang dibuat adalah water closet (WC) yang di bawahnya terdapat beberapa dekker sebagai tempat menampung kotoran yang dihasilkan dari buang air besar. Penetapan warga terpilih yang dijadikan aksi pembangunan MCK ini ditetapkan melalui "rembug" komunitas yang didasarkan atas kerentanan dan kebutuhan yang paling mendesak yaitu yang warga yang paling miskin dan penghuninya janda dan orang tua lanjut usia di

Volume 2, Number 1, Mei 2018| 111 Perubahan Perilaku Open Defecation Free (ODF) Melalui Program Sanitasi Total Berbasis Masyarakat (STBM) di Desa Babad Kecamatan Kedungadem Kabupaten Bojonegoro 
dusun tersebut. Semua proses aksi pengerjaan pembungan 6 (enam) unit MCK dengan water closet (WC) hasil "urunan" tersebut sebagai "pilot project” ini dilakukan secara partisipatif dan gotong royong bersama warga masyarakat.

Dengan terselesaikannya pembuatan enam (6) unit sarana MCK pada enam (6) rumah secara berbeda pada warga miskin ini diharapkan mampu memumbuhkan rasa ingin memiliki sarana MCK secara mandiri bagi warga yang lain. Dengan menetapkan warga kurang (miskin) sebagai sasaran aksi partisipatori ini, diharapkan dapat menjadi pemicu bagai warga masyarakat yang lain yang lebih mampu dan kaya untuk membuat sarana MCK yang layak. Dengan proses pendampingan yang berkelanjutan, pelaksanaan penyediaan MCK berbasis komunitas tersebut diharapkan dapat mengubah pola pikir masyarakat tentang pentingnya sarana MCK. Dari aksi pembuatan sarana MCK ini diperoleh pembelajaran bagi warga masyarakat bahwa ternyata tidak perlu mengeluarkan biaya yang besar, yang terpenting sarana MCK tersebut dapat berfungsi dan memenuhi kriteria kesehatan. Hasil akhir yang diharapkan secara keseluruhan masyarakat Desa Babad atas kesadarannya sendiri memiliki sarana MCK yang layak secara mandiri di masing-masing rumah sehingga mereka dapat dengan mudah buang air besar (BAB) tanpa harus khawatir keselamatan dan keamanan saat buang air besar.

Kesadaran yang dipicu dari aksi partisipatif warga masyarakat tersebut dalam perkembangan selanjutnya mempengaruhi perilaku warga masyarakat Desa Babad. Dampaknya, beberapa hari kemudian terbentuk kelompok-kelompok kecil (core group) di setiap RT dan beberapa kumpulan jama'ah yasinan tablilin mengadakan "rembug" atau focus group discussion (FGD) terkait bagaimana pelaksanaan pembuatan MCK dengan water closet (WC) yang murah. Melalui kegiatankegiatan dalam pertemuan focus group discussion (FGD), tim fasilitator mendampingi pelaksanaan kegiatan lanjutan yaitu pembuatan sarana MCK melalui program Sanitasi Total Berbasis Masyarakat (STBM). Kegiatan pilot project dusun bebas ODF adalah Dusun Banaran, dari 242 rumah (KK), hampir semuanya sudah mulai membuat MCK yang layak. Melalui “rembug” Desa ditetapkan beberapa kegiatan untuk mensukseskan program "Desa Babad bebas ODF" yang telah dicanangkan oleh pemerintah desa. Salah satu kegiatan untuk mendiseminasikan atau menyebarluaskan hasil kegiatan pembuatan sarana MCK berbasis partisipasi komunitas ini adalah dengan membuat filam "Layanan Masyarakat Bebas ODF”. Film yang diperankan seluruhnya oleh warga setempat ini menjadi media sosialisasi bebas ODF kepada warga masyarakat.

Berdasarkan hasil pendampingan komunitas dalam upaya perubahan perilaku open defecation free (ODF) melalui program Sanitasi Total Berbasis Masyarakat (STBM) tersebut di atas 
menunjukkan bahwa keberhasilan program sangat dipengaruhi oleh ketersediaan sanitasi, dukungan semua pihak, dan perubahan pemahaman masyarakat tentang ODF. Hal ini mendukung hasil penelitian Febriani dkk. bahwa keberhasilan program STBM dipengaruhi oleh akses/ketersediaan sanitasi, pengetahuan, dukungan sosial, sikap dan keyakinan masyarakat di desa. ${ }^{23}$ Melalui penayangan film "Layanan Masyarakat Bebas ODF” secara massif di komunitas, sedikit demi sedikit warga masyarakat mulai sadar akan bahaya ODF dan berubah dari berperilaku buang air besar (BAB) sembarangan ke penggunaan MCK saat buang air besar (BAB). Penelitian ini mundukung hasil penelitian Cintya bahwa pengetahuan sangat mempengaruhi perilaku buang air besar (BAB) sembarangan. ${ }^{24}$

Pelaksanaan program Sanitasi Total Berbasis Masyarakat (STBM) yang dilaksanakan oleh peneliti melibatkan partisipasi komunitas. Sebagaimana temuan Resti dan Najmah yang menguatkan peran program Sanitasi Total Berbasis Masyarakat (STBM) sangat mempengaruhi perilaku buang air besar (BAB) ${ }^{25}$ Program Sanitasi Total Berbasis Masyarakat (STBM) sebagai upaya pemicuan juga sangat efektif terhadap perilaku kesehatan masyarakat sehingga masayarakt tidak lagi buang air besar (BAB) sembarangan. ${ }^{26}$ Perubahan perilaku open defecation free (ODF) melalui program Sanitasi Total Berbasis Masyarakat (STBM) secara partisipatif dengan melibatkan dan bermitra dengan stakeholders sangat didukung oleh pemerintah Desa. Hal itu karena program open defecation free (ODF) itu sudah dicanangkan oleh Pemerintah Kabupaten Bojonegoro lewat Program Desa bebas ODF yang merupakan implementasi dari Program GDSC (Gerakan Desa Sehat dan Cerdas). Sebagaimana hasil penelitian Sholikhah bahwa program ini secara signifikan telah terbukti di lapangan dalam mengupayakan perubahan perilaku masyarakat dalam buang air besar di luar jamban. ${ }^{27}$ Pelibatan pemangku kepentingan (stakeholders) dalam program Sanitasi Total Berbasis Masyarakat (STBM) seperti Dinas Kesehatan, PUSKESMAS, dan Bidan Desa sangat

${ }^{23}$ W. Febriani, Samino, \& N. Sari, "Faktor Yang Mempengaruhi Perilaku Stop Buang Air Besar Sembarangan (BABS): Studi Pada Program STBM di Desa Sumbersari Metro Selatan 2016. Dunia Kesmas, 5, Nomor 3, 2016.

${ }^{4}$ C.V.D.Cintya, "Hubungan Pengetahuan Masyarakat Tentang Program ODF (Open Defecation Free) dengan Perilaku Buang Air Besar Sembarangan. Jurnal Keperawatan Dan Kebidanan, (Imd), (2016). 19-25.

${ }^{25}$ Resti Irmalasari, Najmah, N. A. F., "Studi Komparatif Perilaku Buang Air Besar pada Masyarakat yang Telah dan Belum Menerapkan Program Sanitasi Total Berbasis Masyarakat (STBM) di Kecamatan Inderalaya. Jurnal Ilmu Kesehatan Masyarakat, 2(03), 2011. 181-188.

${ }^{26}$ M. Nugraha, "Dampak Program Sanitasi Total Berbasis Masyarakat (STBM) Pilar Pertama di Desa Gucialit Kecamatan Gucialit Kabupaten Lumajang”. Journal Unair. 3(2014), 44-53. Retrieved from http://journal.unair.ac.id/filerPDF/kmp62b069aeb2full.pdf

${ }^{27}$ S. Sholikhah, "Hubungan Pelaksanaan Program ODF (Open Defecation Free) dengan Perubahan Perilaku Masyarakat dalam Buang Air Besar di Luar Jamban di Desa Kemiri Kecamatan Malo Kabupaten Bojonegoro Tahun 2012”. Jurnal Surya, 02(XVIII), 2014. 84-90.

Volume 2, Number 1, Mei 2018| 113 Perubahan Perilaku Open Defecation Free (ODF) Melalui Program Sanitasi Total Berbasis Masyarakat (STBM) di Desa Babad Kecamatan Kedungadem Kabupaten Bojonegoro 
membantu terhadap perubahan perilaku open defecation free (ODF). ${ }^{28}$

Peran aparatur dan pamong desa dalam pelaksanaan program Sanitasi Total Berbasis Masyarakat (STBM) dalam upaya mengubah kebiasan masyarakat buang air besar (BAB) sangat penting sekali. Misalnya membuat peraturan desa (PERDES) tentang larangan dan denda bagi yang melanggar peraturan tersebut. ${ }^{29}$ Namun, di beberapa tempat masih belum ada dukungan dari pemerintah daerah. ${ }^{30}$ Ada beberapa faktor yang mempengaruhi keberhasilan program Sanitasi Total Berbasis Masyarakat (STBM) yaitu antara lain faktor lingkungan, sumber daya alam, sumber daya manusia, regulasi/peraturan desa (PERDES), pengetahuan komunitas tentang sanitasi, dan faktor pendanaan atau biaya. Namun, temuan Priatno dkk. menunjukkan bahwa faktor lingkungan dan kondisi alam paling tinggi pengaruhnya terhadap keberhasilan program Sanitasi Total Berbasis Masyarakat (STBM) dalam upaya mengubah perilaku open defecation free (ODF). ${ }^{31}$ Temuan ini menjadi penting karena keberhasilan program Sanitasi Total Berbasis Masyarakat (STBM) sangat tergantung dari ketersediaan air bersih, dan kondisi lingkungan alam yang kering (kurang air). Temuan yang sama juga ditunjukkan oleh Sugiharto dan Choiriyah bahwa keberhasilan program juga sangat dipengaruhi oleh kondisi alam komunitas. ${ }^{32}$

Temuan penilitian ini menunjukan bahwa tingkat partisipasi warga masyarakat dalam kegiatan program Sanitasi Total Berbasis Masyarakat (STBM) sangat berpengaruh terhadap perubahan perilaku open defecation free (ODF). Hal itu sebagaimana temuan Zahrina dan Suryadi menunjukan bahwa implementasi program Sanitasi Total Berbasis Masyarakat (STBM) berhasil karena melalui peran aktif dan partisipasi masyarakat serta dukungan dari pemerintah desa. ${ }^{33}$ Partisipasi warga masyarakat dalam pembiayaan penyelenggaraan program Sanitasi Total Berbasis

${ }^{28}$ Sutiyono, Z. Shaluhiyah, \& C.T. Purnami, “Analisis Pelaksanaan Program Sanitasi Total Berbasis Masyarakat ( STBM) Sebagai Strategi Peningkatan Perilaku Hidup Bersih dan Sehat ( PPHBS ) Masyarakat oleh Petugas Puskesmas Kabupaten Grobogan”. Jurnal Manajemen Kesehatan Indonesia, 02(01), 2014. 26-35.

${ }^{29}$ S. Wahyuni, O. Setiani, \& Suharyanto. "Implementasi Kebijakan Pembangunan Dan Penataan Sanitasi Perkotaan Melalui Program Sanitasi Lingkungan Berbasis Masyarakat Di Kabupaten Tulungagung”. Jurnal Ilmu Lingkungan, 10(Vol 10, No 2. 2012. 111-122. Retrieved http://doi.org/10.14710/jil.10.2.111-122.

30 Ichwanudin. "Kajian Dampak Sanitasi Total Berbasis Masyarakat Terhadap Akses Sanitasi di Kabupaten Wonogiri”. Jurnal Kesehatan Lingkungan Indonesia, 15(2), 2016. 46-49. https://doi.org/10.14710/jkli.15.2.46-49.

31 Priatno, Teguh., Zauhar, Soesilo., \& I. Hanafi, "Faktor-Faktor yang Berpengaruh terhadap Keberhasilan Program Sanitasi Total Berbasis Masyarakat (STBM) di Kota Tasikmalaya. Journal Kesehatan Komunitas Indonesia, 10(2), 2014.1038-1053.

32 Sugihartoyo, \& N. Choiriyyah, N. "Identifikasi Pelaksanaan Kegiatan Program Sanitasi Berbasis Masyarakat (SANIMAS) Di Kampung Pulo, Desa Gintung, Kecamatan Sukadiri, Kabupaten Tangerang”. Jurnal Planesa, 2(1), 2011. 73-79.

33 Aida Fitria Zahrina \& S. Suryadi, S. "Implementasi Program Gerakan Sanitasi Berbasis Masyarakat dalam Pengendalian Lingkungan ( Studi Kasus pada Desa Perning, Kecamatan Jatikalen , Kabupaten Nganjuk". Jurnal Administrasi Publik (JAP), 3(11), 2015. 1832-1836.

Volume 2, Number 1, Mei 2018| 114 Perubahan Perilaku Open Defecation Free (ODF) Melalui Program Sanitasi Total Berbasis Masyarakat (STBM) di Desa Babad Kecamatan Kedungadem Kabupaten Bojonegoro 
Masyarakat (STBM) sangat berperan terhadap keberhasilan upaya perubahan perilaku open defecation free (ODF). ${ }^{34}$ Temuan Zuliyanto juga menunjukan bahwa analisis aspek teknis, aspek pembiayaan dan analisis aspek peran serta masyarakat sangat berperan dalam penyelesaian masalah ODF. ${ }^{35}$

Peran serta warga masyarakat dalam pembiayaan program dan juga partisipasi keberlanjutan program melalui perawatan sistem pengelolaan sangat berperan dalam menyelesaikan persoalan sanitasi di masyarakat. ${ }^{36}$ Oleh karena itu, keberhasilan program Sanitasi Total Berbasis Masyarakat (STBM) dapat diukur dari keseluruhan rangkaian kegiatan mulai dari proses perencanaan program, pengorganisasian komunitas, implementasi, sampai dengan monitoring dan evaluasi harus berbasis partisipasi komunitas. ${ }^{37}$ Pelibatan secara total dalam pelaksanaan program Sanitasi Total Berbasis Masyarakat (STBM) terutama saat perencanaan dan pelaksaan juga ditemukan dalam penelitian Windraswara. ${ }^{38}$ Pelibatan komunitas dalam keberlanjutan program juga menjadi aspek yang penting dalam pelaksanaan pelaksanaan program Sanitasi Total Berbasis Masyarakat (STBM). ${ }^{39}$ Untuk meningkatkan efektifitas pelaksanaan program Sanitasi Berbasis Masyarakat (STBM) memerlukan advokasi dan keberpihakan terhadap masyarakat agar program terjaga keberlanjutan program. ${ }^{40}$ Berdasarkan penjelasan ini dapat dipahami bahwa keberhasilan program Sanitasi Berbasis Masyarakat (STBM) sebagai upaya perubahan perilaku open defecation free (ODF) sangat ditentukan oleh tingkat partisipasi warga masyarakat dalam perencanaan, pelaksanaan, evaluasi dan sampai keberlanjutan program.

${ }^{34}$ Sri Wahyuni \& S. Onny Setiani, “Tingkat Partisipasi Masyarakat dalam Pelaksanaan Program Sanitasi Lingkungan Berbasis Masyarakat di Kabupaten Tulungagung”. Prosiding Seminar Nasional Pengelolaan Sumberdaya Alam Dan Lingkungan, (September), 2012. 77-85.

35 A. Zuliyanto, "Strategi Pengelolaan Air Iimbah Domestik di Kecamatan Lamongan Kabupaten Lamongan. Jurnal Teknika, 2(2), 2010. 17-24.

${ }^{36}$ Y.V. Afandi YV, K. Sunoko HR, "Status Keberlanjutan Sistem Pengelolaan Air Limbah Domestik Komunal Berbasis Masyarakat di Kota Probolinggo”. Jurnal Ilmu Lingkungan, 11(2), 2013. 100-109. https://doi.org/10.14710/jil.11.2.100-109.

${ }^{37}$ Ashari, Agus Erwin Ashari \& F. Akbar, "Evaluasi Program Sanitasi Total Berbasis Masyarakat Di Kabupaten Mamuju. Jurnal Kesehatan Manarang, 2(1), 2016. 6-14.

${ }^{38}$ R. Windraswara, "Keterlibatan Komunitas Dalam Perencanaan Sanitasi Pada Daerah Rawan Bencana”. Jurnal Kesehatan Masyarakat, 5(1), 2009. 58-63.

${ }^{39}$ Yulis, Indriyani, Yuniarti, \& R.V.N. Latif, "Kajian Strategi Promosi Kesehatan Sanitasi Total Berbasis Masyarakat (STBM) Kelurahan Tirto Kota Pekalongan”. Unnes Journal of Public Health, 5(3), 2016. $240-251$. https://doi.org/10.1177/1403494814549494.

${ }^{40}$ F. Salesman, "Effectiveness of Health Promotion to Community-Based Total Sanitation Outcomes in Nunsaen, Kupang, Indonesia”. Jurnal Studi Komunikasi, 1(21). 2018. https://doi.org/10.25139/jsk.v2i1.467.

Volume 2, Number 1, Mei 2018| 115 Perubahan Perilaku Open Defecation Free (ODF) Melalui Program Sanitasi Total Berbasis Masyarakat (STBM) di Desa Babad Kecamatan Kedungadem Kabupaten Bojonegoro 


\section{Simpulan}

Berdasarkan hasil pendampingan komunitas tentang upaya mengubah perilaku perilaku open defecation free (ODF) melalui program Sanitasi Total Berbasis Masyarakat (STBM) dengan menggunakan metode Community-Based Research (CBR) ini dapat disimpulkan bahwa keberhasilan program sangat ditentukan oleh tingkat partisipasi warga masyarakat dalam perencanaan, pelaksanaan, evaluasi dan sampai keberlanjutan program. Hal itu ditunjukkan oleh munculnya kesadaran warga masyarakat untuk mengubah perilaku open defecation free (ODF) dan secara mandiri mampu menyelesaikan masalah sanitasi berbasis komunitas dengan membangun sarana MCK yang layak secara partisipatif. Temuan penelitian menunjukkan bahwa upaya perubahan perilaku open defecation free (ODF) melalui program Sanitasi Total Berbasis Masyarakat (STBM) sangat dipengaruhi oleh ketersediaan sanitasi, dukungan semua pihak, dan perubahan pemahaman masyarakat tentang ODF. Program Sanitasi Total Berbasis Masyarakat (STBM) berbasis partisipatif sangat efektif terhadap upaya mengubah perilaku kesehatan masyarakat sehingga masayarakt tidak lagi buang air besar (BAB) sembarangan. Ada beberapa faktor yang mempengaruhi keberhasilan program Sanitasi Total Berbasis Masyarakat (STBM) antara lain faktor lingkungan, sumber daya alam, sumber daya manusia, regulasi/peraturan desa, keterlibatan perangkat desa, pengetahuan komunitas tentang sanitasi, dan faktor pendanaan atau biaya. Peran serta warga masyarakat dalam pembiayaan program dan juga partisipasi keberlanjutan program melalui perawatan sistem pengelolaan sanitasi sangat berperan dalam menyelesaikan persoalan perilaku open defecation free (ODF).

\section{Daftar Pustaka}

A. Zuliyanto, "Strategi Pengelolaan Air Iimbah Domestik di Kecamatan Lamongan Kabupaten Lamongan. Jurnal Teknika, 2(2), 2010. 17-24.

Aida Fitria Zahrina \& S. Suryadi, S. "Implementasi Program Gerakan Sanitasi Berbasis Masyarakat dalam Pengendalian Lingkungan (Studi Kasus pada Desa Perning, Kecamatan Jatikalen, Kabupaten Nganjuk". Jurnal Administrasi Publik (JAP), 3(11), 2015. 1832-1836.

Ambar Winarti, Suci Nurmalasari, "Hubungan Perilaku Buang Air Besar (BAB) dengan Kejadian Diare di Desa Krajan Kecamatan Jatinom Kabupaten Klaten, Jurnal Involusi Kebidanan, Vol. 7, No. 12, Juni 2016. 13-25.

Ashari, Agus Erwin Ashari \& F. Akbar, "Evaluasi Program Sanitasi Total Berbasis Masyarakat Di Kabupaten Mamuju. Jurnal Kesehatan Manarang, 2(1), 2016. 6-14.

Baca Rochgianti, "Fungsi Sungai bagi Masyarakat di Tepian Sungai Kuin Kota Banjarmasin”, Jurnal Komunitas 3 (1), 2011. 51-59.

Brenda Roche, New Directions in Community-Based Research, Wellesley Institute, 2008, dikutip

Volume 2, Number 1, Mei 2018| 116

Perubahan Perilaku Open Defecation Free (ODF) Melalui Program Sanitasi Total Berbasis Masyarakat (STBM) di Desa Babad Kecamatan Kedungadem Kabupaten Bojonegoro

Abdul Muhid, Sumarkan, Rakhmawati, Lukman Fahmi 
dari http://www.wellesleyinstitute.com/wp-content/uploads/2011/11/newdirectionsincbr.pdf.

"Bojonegoro Tempo Doeloe" di Blok Bojonegoro: Tabloid Kritis Cerdas dan Terdepan, Edisi Oktober 2014.

Buku Profil Bojonegoro dikutip dari www.kanalbojonegoro.com diunduh pada tanggal 21 Maret 2015.

C.V.D.Cintya, "Hubungan Pengetahuan Masyarakat Tentang Program ODF (Open Defecation Free) dengan Perilaku Buang Air Besar Sembarangan. Jurnal Keperawatan Dan Kebidanan, (Imd), (2016). 19-25.

Cairncross S, Valdmanis, V. "Water Supply: Sanitation and Hygiene Promotion". In: Dean T Jamison ea, editor. Disease Control Priorities in Developing Countries. 2nd edition ed. (Washington DC: World Bank 2006.

Carr R. "Excreta-related infections and the role of sanitation in the control of transmission". In: Bartram LFaJ, editor. Water Quality: Guidelines, Standards and Health. (London: IWA Publisihing 2001).

F. Salesman, "Effectiveness of Health Promotion to Community-Based Total Sanitation Outcomes in Nunsaen, Kupang, Indonesia". Jurnal Studi Komunikasi, 1(21). 2018. https://doi.org/10.25139/jsk.v2i1.467.

Farah Nur Amalina Nurjanah Massudi Suwand, Perilaku Bab Di Sungai Pada Warga Di Kelurahan Sekayu Semarang Tabun 2014. Fakultas Kesehatan Universitas Dian Nuswantoro Semarang.

Hanafi, dkk., Community-Based Research: Panduan Merancang dan Melaksanakan Penelitian Bersama Komunitas, (Surabaya: LP2M UIN Sunan Ampel Surabaya bekerjasama dengan Dwiputra Pustaka Jaya, 2015).

Harian Bhirawa Edisi 17 Pebruari 2015.

Ichwanudin. "Kajian Dampak Sanitasi Total Berbasis Masyarakat Terhadap Akses Sanitasi di Kabupaten Wonogiri". Jurnal Kesehatan Lingkungan Indonesia, 15(2), 2016. 46-49. https://doi.org/10.14710/jkli.15.2.46-49.

Joanna Ochocka, Materi Training CBR in CCBR-Kitchener Canada, Oktober, 2014

Keusch GT, Fontaine, O. Bhargava, A. et.al. "Diarrheal Diseases”. In: Jamison DT, editor. Disease Control Priorities in Developing Countries. 2nd edition. (Washington DC: World Bank 2006).

M. Nugraha, "Dampak Program Sanitasi Total Berbasis Masyarakat (STBM) Pilar Pertama di Desa Gucialit Kecamatan Gucialit Kabupaten Lumajang”. Journal Unair. 3(2014), 44-53. Retrieved from http://journal.unair.ac.id/filerPDF/kmp62b069aeb2full.pdf

Miftakhul Rizeki Hardiyansah dkk. "Membebaskan Masyarakat Dari Perilaku ODF Menuju Desa Sehat: Pendampingan Warga dalam Mengubah Kebiasaan Buang Air Besar Sembarangan di Sungai Menjadi Buang Air Besar di WC di Dusun Banaran Desa Babad Kecamatan Kedungadem Kabupaten Bojonegoro". LP2M UINSA: Laporan KKN Transformatif Tabun 2015. Tidak Diterbitkan.

Mukherjee N. Factors Associated with Achieving and Sustaining Open Defecation Free Communities: Learning from East Java. Water Sanitation Program (WSP): Research Breaf. September 2011.

Notoatmodjo, S. Pendidikan dan Perilaku Kesehatan. (Jakarta: Rineka Cipta, 2003).

Volume 2, Number 1, Mei 2018| 117

Perubahan Perilaku Open Defecation Free (ODF) Melalui Program Sanitasi Total Berbasis Masyarakat (STBM) di Desa Babad Kecamatan Kedungadem Kabupaten Bojonegoro

Abdul Muhid, Sumarkan, Rakhmawati, Lukman Fahmi 
Nur Apriatman, Stop Buang Air Besar Sembarangan: Pembelajaran dari Pegiat Community Led-Total Sanitation (CLTS). Waspola Facility, Februari 2012.

Priatno, Teguh., Zauhar, Soesilo., \& I. Hanafi, "Faktor-Faktor yang Berpengaruh terhadap Keberhasilan Program Sanitasi Total Berbasis Masyarakat (STBM) di Kota Tasikmalaya. Journal Kesehatan Komunitas Indonesia, 10(2), 2014.1038-1053.

R. Windraswara, "Keterlibatan Komunitas Dalam Perencanaan Sanitasi Pada Daerah Rawan Bencana”. Jurnal Kesehatan Masyarakat, 5(1), 2009. 58-63.

Resti Irmalasari, Najmah, N. A. F., "Studi Komparatif Perilaku Buang Air Besar pada Masyarakat yang Telah dan Belum Menerapkan Program Sanitasi Total Berbasis Masyarakat (STBM) di Kecamatan Inderalaya. Jurnal Ilmu Kesehatan Masyarakat, 2(03), 2011. 181-188.

S. Sholikhah, "Hubungan Pelaksanaan Program ODF (Open Defecation Free) dengan Perubahan Perilaku Masyarakat dalam Buang Air Besar di Luar Jamban di Desa Kemiri Kecamatan Malo Kabupaten Bojonegoro Tahun 2012”. Jurnal Surya, 02(XVIII), 2014. 84-90.

S. Wahyuni, O. Setiani, \& Suharyanto. "Implementasi Kebijakan Pembangunan Dan Penataan Sanitasi Perkotaan Melalui Program Sanitasi Lingkungan Berbasis Masyarakat Di Kabupaten Tulungagung". Jurnal Ilmu Lingkungan, 10(Vol 10, No 2. 2012. 111-122. Retrieved http://doi.org/10.14710/jil.10.2.111-122.

Salma Galal et. all. "Infections in children under 5 years old and latrine cleanliness". International Journal of Environmental Health Research. 2001, (11):337-41.

Slamet. J. S. Kesehatan Lingkungan. (Yogyakarta: UGM Press, 2006).

Sri Wahyuni \& S. Onny Setiani, "Tingkat Partisipasi Masyarakat dalam Pelaksanaan Program Sanitasi Lingkungan Berbasis Masyarakat di Kabupaten Tulungagung”. Prosiding Seminar Nasional Pengelolaan Sumberdaya Alam Dan Lingkungan, (September), 2012. 77-85.

Stephen Kemmis and Robin Mc. Taggart, Participatory Action Research dalam Norman K. Denzin \& Yvonna S. Lincoln, Handbook of Qualitative Research (California: Sage Publication, 2000).

Sugihartoyo, \& N. Choiriyyah, N. "Identifikasi Pelaksanaan Kegiatan Program Sanitasi Berbasis Masyarakat (SANIMAS) Di Kampung Pulo, Desa Gintung, Kecamatan Sukadiri, Kabupaten Tangerang". Jurnal Planesa, 2(1), 2011. 73-79.

Sutiyono, Z. Shaluhiyah, \& C.T. Purnami, "Analisis Pelaksanaan Program Sanitasi Total Berbasis Masyarakat ( STBM ) Sebagai Strategi Peningkatan Perilaku Hidup Bersih dan Sehat ( PPHBS ) Masyarakat oleh Petugas Puskesmas Kabupaten Grobogan". Jurnal Manajemen Kesehatan Indonesia, 02(01), 2014. 26-35.

Umar Zein, Khalid Huda Sagala, Josia Ginting. "Diare Akut Disebabkan Bakteri". Fakultas Kedokteran Divisi Penyakit Tropik dan Infeksi Bagian Ilmu Penyakit Dalam Universitas Sumatera Utara. Laporan Penelitian diunduh dari e-USU Repository C2004 Universitas Sumatera Utara.

W. Febriani, Samino, \& N. Sari, "Faktor Yang Mempengaruhi Perilaku Stop Buang Air Besar Sembarangan (BABS): Studi Pada Program STBM di Desa Sumbersari Metro Selatan 2016. Dunia Kesmas, 5, Nomor 3, 2016.

Wagner EG, Lanoix,J.N. "Excreta Disposal for Rural Areas and Small Communities". WHO. 1958. Monograph Series. No.39:9-24.

Volume 2, Number 1, Mei 2018| 118

Perubahan Perilaku Open Defecation Free (ODF) Melalui Program Sanitasi Total Berbasis Masyarakat (STBM) di Desa Babad Kecamatan Kedungadem Kabupaten Bojonegoro

Abdul Muhid, Sumarkan, Rakhmawati, Lukman Fahmi 
WHO/UNICEF. Progress on Sanitation and Drinking-water. 2010 Update. Geneva: WHO 2010. p. 22$52)$;

www.sanitasi.net; www.ampl.or.id ; dan www.stbm-indonesia.or.id

Y.V. Afandi YV, K. Sunoko HR, "Status Keberlanjutan Sistem Pengelolaan Air Limbah Domestik Komunal Berbasis Masyarakat di Kota Probolinggo". Jurnal Ilmu Lingkungan, 11(2), 2013. 100-109. https://doi.org/10.14710/jil.11.2.100-109.

Yulis, Indriyani, Yuniarti, \& R.V.N. Latif, "Kajian Strategi Promosi Kesehatan Sanitasi Total Berbasis Masyarakat (STBM) Kelurahan Tirto Kota Pekalongan". Unnes Journal of Public Health, 5(3), 2016. 240-251. https://doi.org/10.1177/1403494814549494. 